\title{
除草剤の作用機構研究における生理生化学的技法
}

\author{
松 中 昭一 \\ 神戸大学農学部植物防疫学科農薬学講座 \\ (昭和 54 年 9 月 17 日受理)
}

\section{Physiological and Biochemical Techniques in Research on Mode of Action of Herbicides}

\author{
Shooichi Matsunaka \\ Department of Plant Protection, Faculty of Agriculture, \\ Kobe University, Nada-ku, Kobe 657, Japan
}

\section{は じめに}

このシリーズの解説は, 農薬研究における生理生化学 的な手法をテーマにしており, 筆者への割当はその除草 剂分野である.除草剤研究の生理生化学的な手法といっ ても, これはかなり広範囲なもので, その作用機構・選 択性機構・代謝（分解や抱合）など，限られた紙数で全 部を紹介することは困難である.したがって，ここでは 除草刘の作用機構に関する手法を主体にしたいと思う。

除草剤の作用機構に関する手法に限定しても, これま た, より限定する必要がでてくる. 数多くの研究者の採 用している手法を網羅的に記述することは無理である し，またこれらの手法を相互に実証的に比較して一番良 いものを紹介すれば良いのであるが，これも筆者には任 が重すぎる，丁度幸い，アメリカの EPA の林文彦博士 がプロジェクトオフィサーになって，之シガン大学の研 究者グループの協力を得て従来の方法に検討を加え, 新 しい方法の開発をもふくめて総合的な研究成果として提 出させた 部厚い報告書（林博士のご厚意でいただいた） が手許にあるので，これを中心にして書いていくことに する.

この報告書は EPA Project No. 68-01-1907 および 2482 による Rapid Screening Technique (Biochemical Method for Phytotoxicity): Modes-of-Action of Herbicides と題され Part-I (208 頁) および Part-II (125 頁）より成り立っている。そもそもは，EPAの the Sub- stitute Chemical Program (SCP $)^{1)}$ によって, 問題のあ る農薬に代替すべき新農薬を速やかに実用化するための 対策（その作用機構を知ることも必要）のひとつとして 計画されたものである. 除草剤の作用機構を調べる目的 で開発されたもの, 従来の手法を比較して改良が加えら れていること，作用機構全体を包含するよう（実際は無 理であるが）計画されていることなどを特徴とするが， アメリカの話であるので使用する器具や薬品等がやや高 級であるという難点はみられる，同時に，関連する手法 は国内で実施されたものについてその文献を紹介してお くので，実行にあたっては十分に比較検討されたい。

上記の報告書には, 植物 ミトコンドリア呼吸, 葉緑体 光合成, クロロフィル螢光, 根端切片の呼吸之葉片光合 成, タンパク質および核酸生合成, 電子顕微鏡像なぞへ の除草剤の影響を調べる手法および検討結果が記述され てある.ここでは, ミトコンドリアの呼吸, 葉緑体の光化 学系, タンパク質および核酸生合成の 3 点をとりあげ,そ のほかに，もうひとつの除草剤のグループであるいわゆ るホルモン型除草剤の作用機構としてのオーキシン作用 の検討手法を別の資料よりとって付記することにする.

\section{呼吸の電子伝達系および酸化的リン酸化への影響}

除草剂の対象となる高等植物も，一部はシアン而性の 呼吸など特殊な面もあるが，本質的な呼吸は動物のそれ と同じでミトコンドリアにおけるチトクローム系に依存 している. 呼吸基質から酸素にいたる電子层達を完成す 
る途中で，その電位差に応じたエネルギー生成をいわゆ る酸化的リン酸化機構を通じて化学エネルギーである ATP に変換している.

この系の阻害剂は，(a) 電子云達系の阻害，(b) 除共 役 (uncoupling), (c) リン酸化の阻害の三つのタイプに 分けられる.実際には，まず植物ミトコンドリアをとり 出し，これに呼吸基質や $\mathrm{ADP}$ 等を与えて呼吸（電子层 達）を行なわせるとともにりン酸化の程度を測定する. この際, 除草剤の共存が, 酸素摂取・酸化還元色素の変 化・チトクローム酸化還元スペクトラム・リン酸化の能 力等にどのような影響を与えるかが検討される.

\section{1. 植物ミトコンドリアの調製法}

植物乏トコンドリアの調製法については，名和と旭 ${ }^{2)}$ の詳細な解説があるし，またミトコンドリア自身からの 膜画分や酵素の 調製についても旭と岩槻3) の解説があ る.ここでは，上記報告書から二つの方法の紹介にとど める.

1）リョクトウ下胚軸からのミトコンドリア調製法

暗黒下で 4 5 日栽培したりョクトウ（ヤエナリ， Phaseolus aureus L.) から下胚軸部分（子葉十上胚軸之 根との間）を鋏で切りとり，少なくとも 2 回蒸溜水で洗 う. 要すれば，冷蒸溜水中，一晚低温室で保存する，以 下の操作はすべて $0^{\circ} \mathrm{C}$ に近い低温下で実施する. 1.5 $\mathrm{kg}$ の下肧軸を蒸溜水で洗ったあと, 約 $2 \mathrm{~cm} に$ に切り, 磨 砕用液に入れる。 その組成は， $0.5 \mathrm{M}$ マンニット，10 $\mathrm{mM}$ リン酸カリウム, $1 \mathrm{mM}$ EDTA, $0.2 \%$ ウシ血清ア ルブミン, $5 \mathrm{mM}$ システインで, システインは磨研直前 に加え， $\mathrm{pH}$ は $10 \mathrm{~N} \mathrm{KOH}$ を用いて 8 とする. 切片と 磨砕液との容積比は $1: 1$ とし，これらを大型乳錸に入 れ，切片の $2 / 3$ がこわれる程度にまで乳棒を用いて磨砕 する.この過程で， $10 \mathrm{~N} \mathrm{KOH}$ を滴下しつつ磨砕液の $\mathrm{pH}$ を 7.2 ないし 7.4 に保持する。この磨砕物をすく なくとも 8 枚のカーゼを通して滤過し，残渣は上述の磨 砕用液の $1 / 3$ 量で再抽出する. 雨滤液を合わせて分別遠 心分離を行なう．粗々トコンドリア分画は， $500 \times g 10$ 分之 $12,000 \times g 15$ 分の間を集め, これを洗浄液 $(0.5 \mathrm{M}$ マンニット， $10 \mathrm{mM}$ リン酸カリウム緩衝液 $\mathrm{pH} 7.4$, $0.2 \%$ ウシ血清アルブミン) $30 \mathrm{ml}$ に懸浊し， $500 \times g 15$ 分の遠心上清を $6,000 \times g$ 15 分の遠心分離で沈降させ, その沈澱を $30 \mathrm{ml}$ の洗浄液に再懸浊し，これを $5,500 \times$ $g$ で遠心分離する.この沈搌は以下洗浄ミトコンドリア $(\mathrm{Mw})$ と呼ばれるが， $\mathrm{ml}$ 当たり約 $40 \mathrm{mg}$ のタンパク 質量となるように少量の洗浄液に懸浊して実験に用いら れる。

2）トウモロコシ幼根からのミトコンドリアの調製
トウモロコシ種子 (Zea mays L., 品種 Michigan Hybrid 200）を次亜塩素酸ナトリウム液で滅菌後，上く水 洗し，一晚吸水させたあと，孔をあけたアルミニウム板 の上で暗黒下 $2 \sim 3$ 日かけて発芽させる. その後 $2 \sim 3$ 日ガラス室においてその根を集め，よく水洗する. $500 \mathrm{~g}$ の根を磨砕用液（マンニットの代わりに $0.7 \mathrm{M}$ ソルビッ 卜を用いる以外はリョクトゥの場合と同じ組成）ととも に大型乳鉢に入れ，鋏でよく切断する.これを，乳棒 で，ほとんどの根がこわれる程度に磨砕する（破砕しす ぎないように留意すること）。 $\mathrm{pH}$ 低下はリョクトウら の場合よりすくないが，やはり $\mathrm{pH} 7.4$ となるよう $5 \mathrm{~N}$ $\mathrm{KOH}$ で調整しながら磨砕する. 以下の操作は（1）の場 合とほぼ同様に行なうが, 残渣の再抽出と低速遠心 (500 $\times g, 10$ 分）とは省略したほうがよい.

トウモロコシ幼根からのミトコンドリア調製は, 収率 の低いこと，根の細胞壁が固いこと，単離したミトコン ドリアがこわれやすいことなどの理由で問題が多い。

以上の 2 例でもわかるように，植物体からのミトコン ドリアの調製は，固い細胞壁が存在するため動物組織で のそれよりむずかしく，磨砕が足りないと収率が悪く， 磨砕しすぎるとミトコンドリア自身をもこわしてしまう というジレンマを内包している。したがって，成熟した イネの地上部などのより固い材料からの調製は大へんむ ずかしいことである.

一般的注意としては，低温で行なうこと，磨砕程度に 留意すること, 磨砕液の $\mathrm{pH}$ を 7.4 程度に保持し続け ること，ポリフェノール酸化物からミトコンドリアを保 護することなどをあげることができる。

その完全な機能が必要で，intact なミトコンドリアを 使いたい時には，上述の分画遠心分離法のみに留めるが (この場合， $\alpha$-ケトグルタール酸や ADP を共有させて おくと保存性がよい)，この方法ではミクロゾームやそ の他の画分もかなり混在する．したがって，ある酵素や 反応がミトコンドリアに偏在することを主張するために は，ショ糖濃度勾配遠心法4)で分画したものを使用する 必要がある。

\section{2. ミトコンドリアの呼吸測定法}

かっては, 呼吸 (酸素摂取) はウィンクラー法5)やワ ールブルグ検圧法 ${ }^{6,7)}$ で測定するのが常法であったが, 現在ではむしろ酸素電極法を用いるのが常法となってい る. 酸素電極法そのものについては成書8) が出版されて いるのでこれを参照されたい，筆者等はイギリスの Rank Brother's 社製のものを使用している（株式会社三 啓（Tel. 03-834-7331）が輸入してくれる.記録計別で 一式約 7 万円). 
上記 EPA の報告書で Ikuma らが使用しているのは Yellow Springs Instrument 社製の電極で，電気回路は Estabrook の方法9) による自家製である. 反応容器の容 積は $3 \mathrm{ml}$ で $25^{\circ} \mathrm{C}$ にして使用している. 標準反応液の 組成は， $0.5 \mathrm{M}$ マンニット(リョクトゥ用)，または 0.7 $\mathrm{M}$ ソルビット (トウモロコシ用), $10 \mathrm{mM}$ リン酸緩衝液 $\mathrm{pH} 7.2,10 \mathrm{mM} \mathrm{KCl}, 5 \mathrm{mM} \mathrm{MgCl}_{2}$ である. 反応途中 での添加物の量は $5 \sim 60 \mu 1$ にとどめている. また，除 草剂は水に不溶性・難溶性のものが多いので, ジメチル スルホキサイド (DMSO) とともに使用されるが，反応 容器内での DMSO 最終濃度が $1 \%$ 以下であればるト コンドリア活性に影響はない。

\section{3. 酸素電極による測定結果の考察}

酸素電極を用いてミトコンドリアによる酸素摂取のト レースをみるとき，Fig. 1 に示すように， Mw のみの 添加ではその速度はほとんど増加しない。呼吸基質（リ ンゴ酸やコハク酸）か加えるとすこし増加する（この状 態を State 4 の乎ぶ $)^{10)}$. これに ADP を加えるとリン 酸化反応を伴なって呼吸速度が激増する（これが State 3). そして State $3 /$ State 4 の呼吸能の比を呼吸調節比 とよぶが，intact なミトコンドリアほどこの比の值は大 きい.さて，与えた ADP が全部 ATP に変えられると 呼吸速度はまた低下して State 4 に戻るが，ここで供試 除草剂を加兄てみる（最終濃度で $10^{-4} \sim 10^{-2} \mathrm{M}$ 程度）.

この除草剤が呼吸系に無影響のものであれば，トレー ス (1) のように速度は変わらず，これに再度 $\mathrm{ADP}$ を加 えると呼吸速度を増し State 3 の状態を再現し，ADP $\rightarrow$

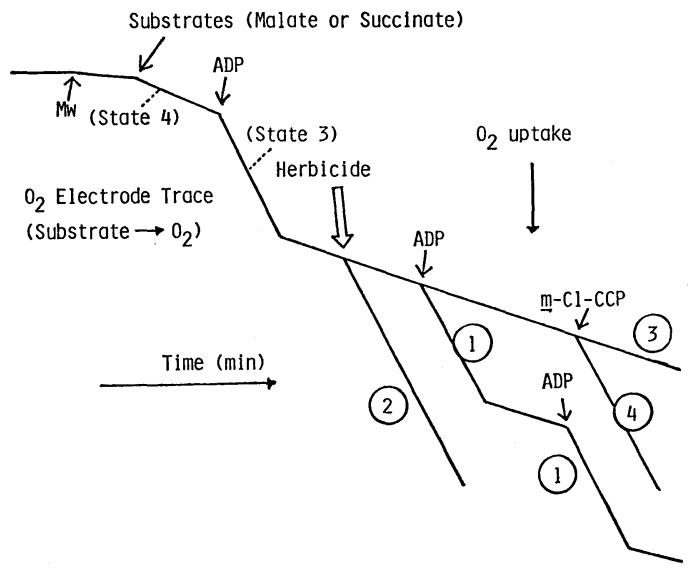

Fig. 1 Effect of herbicide on oxygen electrode trace by plant mitochondria.

(1) no effect, (2) uncoupling, (3) inhibition of electron transfer, (4) inhibition of phosphorylation, $\mathrm{Mw}$ : washed mitochondoria
ATP の反応が終るとまた State 4 になり， 3 度目の $\mathrm{ADP}$ 添加でまた State 3 となる.

もし供試除草剂に除共役作用があれば，添加後ただち に呼吸速度が増加し, State 3 同様の状態を招来する(ト レース (2，ただし ATP の生合成は行なわれていない).

また，抗生物質オリゴマイシンのようなリン酸化の阻 害剂であれば，添加後の呼吸速度は変わらないが，再度 の $\mathrm{ADP}$ 添加でも呼吸増加はなく, 除共役剂 (uncoupler) であるカルボニルシアナイド $m$-クロロフェニルヒドラ ゾン $(m-\mathrm{Cl}-\mathrm{CCP})$ の添加ではじめてトレース (4) のよ うに增加し State 3 の状態となる。

除草剤が単なる電子伝達系の阻害剤であれば，ふつう 添加後急に変化することはない（強力であればすぐ水平 になってしまう）が，ADP 添加でも除共役剤 ( $m-\mathrm{Cl}-$ $\mathrm{CCP}$ 添加でも呼吸上昇を示すことなく，そのままの呼 吸速度を示し漸次弱くなっていく（トレース (3)).

以上のような経過で本項の最初に述べた阻害の三つの タイプ（電子伝達阻害，除共役，リン酸化阻害）を区別 判定することができよう。また，リン酸化阻害剤につい ては ATP アーゼへの影響, 電子伝達系阻害であれば 系のどこで阻害をおこすかなどが調べられる．後者につ いては，別の呼吸基質を用いて回復があるかどうか（酸 素電極法)，チトクローム酸化醅素系に影響があるかど うか(酸素電極法または分光光度計利用), あるいは各 チトクローム成分の酸化還元像をシアン化物や抗生物質 アンチマイシンAなどとの組合せで追求する（自記式分 光光度計）などして検討する.

上記の酸素電極法を用いて Ikuma らが 17 種の除草剂 を検討した結果では，リョクトウとトウモロコシとの間 で大きな差はなく，またその結果は他の研究者の得た結 果ともよく一致している。このことから，ミトコンドリ アレベルでは，呼吸系の阻害剤は種間差をこえて同様に 作用しているといえる.そして， intact なるトコンドリ アの得られる植物材料であれば，リョクトウなどでなく て身近のものでも使用できるといいらる反面，植物種間 のいわゆる選択性については，逆にミトコンドリアの実 験では何もいえないともいえる。 また，ミトコンドリア はより inpact であれば物質の透過性がより低下する場 合もあるので，阻害がみられない場合にはそ物質の不 透過性についても考慮する必要がある.

筆者はかって，ワールブルグ検圧計および無機りンの 定量という古典的方法で PCP の作用機構が除共役剤と しての作用であることを報告している11). 


\section{葉緑体の光化学系への影響}

光合成阻害は除草剂作用機構中最重要なものであり, 多くの除草剤がこの作用点をもつのみでなく，低濃度 で有効なことおよびこの作用機構をもつ除草剤は一般に 動物に対して低毒性であることなどの点からも注目され る.

ここ 20 年来の生化学の示すところによれば，光合成 の本質は二酸化炭素の固定よりも光エネルギーの化学エ ネルギーへの変換（還元力 NADPH の形成をもふくめ て）にあるようで，除草剤の作用点もこの明反応系，す なわち光化学系に見いだされることが多い. 光化学系の 系の阻害は，丁度呼吸の電子伝達系におけるように， (a) 電子云達系の阻害（いわゆる Hill 反応阻害として とらえられる)，（b）除共役，（c）リン酸化の阻害の三 つに分けうる. Moreland らはさらにもう二つのグルー プを追加しているが，詳細は筆者の紹介 ${ }^{12)}$ を参照され たい.

\section{1. 葉緑体の分離調製法}

生葉から調製された葉緑体は，その完全性やこわれ具 合からいくつかの名称で分類される ${ }^{13)}$ が，除草剤の影 響を久る場合には，完全葉緑体（タイプ A)，破壊葉緑 体 (タイプ C)，または葉緑体断片（タイプ $\mathrm{E}$ ) 等が重 要と考兄られる.タイプ $\mathrm{A}$ は，ほぼ完全な $\mathrm{CO}_{2}$ 固定能 と $\mathrm{O}_{2}$ 発生能とをもつが， NADP やフェリシアナイド (Hill 反応に用いられる) の透過性はない. C または $\mathrm{E}$ は，NADP やフェリシアナイドなどの透過性が大きく， 光りン酸化反応や Hill 反応活性の測定によく用いられ る. タイプ $\mathrm{E}$ のほうは，電子层達速度は大きいが，光 リン酸化能は低い。

以下に，タイプ $\mathrm{A}, \mathrm{C}$ おび $\mathrm{E}$ の調製法を述べたあ と, 上記 $\mathrm{EPA} の$ 報告書に記載された調製法にもふれる ことにする.

1）完全葉緑体（タイプA）の調製法

Cockburn らの原法にしたがって宮地 ${ }^{13)}$ が紹介してい る方法を述べる.よく水洗して小さく切断したホウレン ソウ葉 $50 \mathrm{~g}$ に磨砕液 $\left(0.33 \mathrm{M}\right.$ ソルビット, $5 \mathrm{mM} \mathrm{MgCl}_{2}$, $2 \mathrm{mM}$ イソアスコルビン酸*, $10 \mathrm{mM} \mathrm{Na}{ }_{4} \mathrm{P}_{2} \mathrm{O}_{1} \cdot 10 \mathrm{H}_{2} \mathrm{O} * *$ ) とともにワーリングブレンダーに入れ，5 秒間磨砕し， 8 首のガーゼで濾過し, 濾液を $2,500 \times g \quad 50$ 秒間遠心 分離し，ただちに上清を吸引除去する，沈澱した葉緑体

*他の化合物をすべて溶かしたあと， $\mathrm{pH} を 6.5$ に 調節してから加える.

** $0^{\circ} \mathrm{C} て ゙ \mathrm{pH}$ が下りすぎないよう注意しながら $\mathrm{HCl}$ で $\mathrm{pH} 6.5$ にしてから加える.
は遠心管に入れたまま氷中に保存する。この状態では半 日くらい活性を保つが，反応液に懸浊させると比較的す みやかに $\mathrm{CO}_{2}$ 固定能を失活する.

2）タイプCおよび $\mathrm{E}$ の葉緑体調製法

宮地らの方法 ${ }^{13)}$ を紹介する. かたい葉眽を除いた木 ウレンソウの葉 $40 \mathrm{~g}$ （水洗，冷却したもの）を低温下で $80 \mathrm{ml}$ の磨砕液 $(0.8 \mathrm{M}$ ショ糖, $20 \mathrm{mM}$ トリシン, 10 $\mathrm{mM} \mathrm{NaCl}$ ，全体に $\mathrm{HCl}$ を加えて $\mathrm{pH} 7.9$ とする） と ともにワーリングブレンダーで 15 秒間磨砕する.これ を 8 首のガーゼで滤過し，滤液を $1,000 \times g 1$ 分間遠心 分離し，ただちに上清を $1,500 \times g$ で 7 分間遠心分離す るとその沈澱がクラス $\mathrm{C}$ 葉緑体である。この沈澱を 10 $\mathrm{mM} \mathrm{NaCl}$ 液に懸垂すればクラス $\mathrm{E}$ 葉緑体となるので, 約 20 分後 $10,000 \times g 8$ 分間遠心分離して得た沈澱を $10 \mathrm{mM} \mathrm{NaCl}$ 液に懸浊して使用する.

3） EPA 報告書の Yocum らの葉緑体調製法

$100 \mathrm{~g}$ の新鮮なホウレンソウまたはダイズの葉を，0.4 $\mathrm{M}$ ショ糖, $15 \mathrm{mM} \mathrm{NaCl}, 20 \mathrm{mM}$ トリシン緩衝液 $\mathrm{pH} 8.0$ および $0.2 \%$ ウシ血清アルブミンを含む磨碎用液とと もに，ワーリングブレンダーを用いて $4^{\circ} \mathrm{C}$ で 15 秒間 磨碎する。これを 4 層のガーゼで濾過し，濾液を 1,000 $\times g 1$ 分間遠心分離する. 上清を $5,000 \times g 10$ 分間遠心 分離した沈溉を上記磨研用液に縣浊し，さらに $5,000 \times$ $g$ で 10 分間再び遠心分離する. この沈澱を，クロロフ ィル濃度が $2 \mathrm{mg} / \mathrm{ml}$ となるよう少量の磨研用液に再懸 浊する（この方法で $100 \mathrm{~g}$ のホウレンソウの葉から約 $30 \mathrm{mg}$ のクロロフィル相当の葉緑体が得られる). 再懸 浊した葉緑体は使用前に $-70^{\circ} \mathrm{C}$ で保蔵する。

4）クロロフィル定量法

葉緑体の光化学活性はクロロフィル単位で表現される のでクロロフィルの定量は重要であり, 普通 Arnon の 方法 ${ }^{14)}$ が用いられるが，宮地 ${ }^{13)}$ は次のような方法を紹 介している. $50 \mu \mathrm{l}$ の葉緑体懸垂液を $20 \mathrm{ml}$ の $80 \%$ ア セトンに加えてクロロフィルを抽出し, 遠心分離あるい は暗所で濾過し, 上清または滤液の $652 \mathrm{~nm}$ での四光

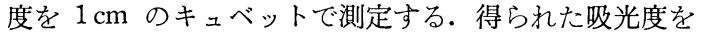
100/9 倍すれば，もとの葉緑体懸垂液 $1 \mu 1$ 中に含まれ るクロロフィル量が $\mathrm{mg}$ 単位で得られる.

\section{EPA 報告書における光化学系への影響検定法}

ミトコンドリアの呼吸への除草剤の影響を検定した方 法と対をなす EPA 報告書の葉緑体光化学系への影響検 定は，やはり酸素電極を用いた次の 3 段階がある.

（1）フェリシアナイドを用い水からの酸素の発生を 調べることによる非環状電子层達（二つの光化学系）へ の影響を検定する。 
（2）光化学系 IIへの影響の夕を検定するため，電子 受容体としてフェリシアナイドを加える以外にフェニレ ンジアミン (PD) をたはジメチルキノン (DMQ) を加 える場合

（3）光化学系 I への影響のみを検定するため, 電子 供与体としてアスコルビン酸, 電子云達中間体としてジ クロロフェノールインドフェノール (DPIP), 電子受容 体としてメチルビオローゲン $(\mathrm{MeV}$ ，パラコート）を用 いる場合. この場合には酸素発生ではなくて酸素摂取を 測定する（還元された $\mathrm{MeV}$ フリーラジカルの自動酸化 による).

すべて基本的反応液は， $12 \mathrm{mM}$ トリシン緩衝液 $(\mathrm{pH}$ 8.0), $60 \mathrm{mM} \mathrm{NaCl}, 2.4 \mathrm{mM}$ フェリシアン化カリ, 10〜 $20 \mu \mathrm{g}$ のクロロフィルを含む葉緑体懸垂液を含む. これ を温度一定にした酸素電極用容器 $(1.6 \mathrm{ml})$ の中で $10^{6} \sim$ $10^{3}$ エルグ $/ \mathrm{cm}^{2} \cdot \mathrm{sec}$ の光で照射して酸素発生を追跡す る. 光化学系 II のみを調べる場合には, 上述のように $0.25 \mathrm{mM}$ の $\mathrm{PD}$ または $\mathrm{DMQ}$ を加える. 光化学系 I の みを調べる場合には，フェリシアン化カリ以外に $60 \mathrm{mM}$ のアスコルビン酸, $6 \mu \mathrm{M} \mathrm{DPIP,} 10 \mu \mathrm{M} \mathrm{MeV}, 7 \mu \mathrm{M}$ の $\mathrm{DCMU}$ (光化学系 II の電子层達阻害の除草剂) を用い, 上述のように酸素摂取を調べる.

検定すべき除草剂は，水，DMSO またはエタノール にとかし， $\mu 1$ 単位で反応液に加える. 光リン酸化反応 の除共役には $20 \mathrm{mM}$ のメチルアミンを用いる.

Fig. 2 の A は, 光化学系 I $\rightarrow$ II を通じての検討であ るが，光照射がはじまると $\mathrm{O}_{2}$ 放出が増加する. 除草剤 が光化学系に無影響であればその速度は変らず, 除共役 剤であるメチルアミンの添加でその速度を増加し(1)よ うなトレースとなる. 加えた除草剤が光化学系 II $\rightarrow I$ の 間の電子伝達によるリン酸化を除共役する場合には, 卜 レースは(2)のようになる. また, それが電子伝達の阻害 を行なう場合には(3)のようなトレースとなり，メチルア ミンの添加でもその速度を変えない. そして, 光リン酸 化の阻害剤であればトレース(4)のような結果となる.

光化学系Iのみへの影響をみる系では, $\mathrm{PD} や \mathrm{DMQ}$ は普通トレース(1)の酸素放出速度を増加させるが, 光化

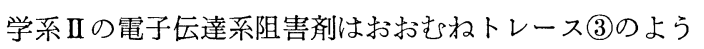
になる.

光化学系 I のみをみる場合には, Fig. 2 B のように, 光照射下でアスコルビン酸+DPIP からの電子が光化 学系Iによりメチルビオローゲンに伝達され，この際 $\mathrm{MeV}$ は一電子還元をうけてフリーラジカルとなり，こ れが普通の 3 重項の酸素と反応して酸化されると, もと の $\mathrm{MeV}$ に戻るので，ここに酸素摂取がみられるわけで

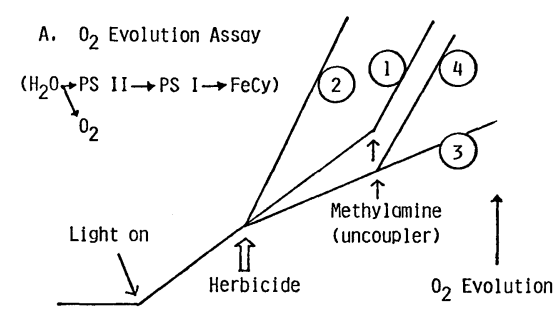

B. $\mathrm{O}_{2}$ Consumption Assay (Ascorbic Acid/DPIP $\rightarrow$ PS I $\rightarrow \mathrm{MeV} \rightarrow \mathrm{O}_{2}$ )

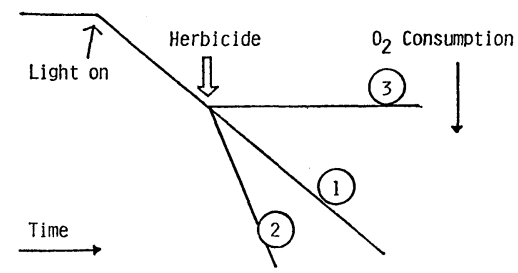

Fig. 2 Effect of herbicide on oxygen electrode trace by chloroplasts.

(1) no effect, (2) uncoupling, (3) inhibition of electron transfer, (4) inhibition of phosphorylation.

ある. (この際, 光化学系 II からの電子层達は DCMU で 阻害してある)Fig. 2 B においても, 供試除草剤が無影 響であればトレース(1)，除共役剂として作用すれば(2)， 電子伝達の阻害剂として作用すれば(3)のような結果が得 られる.

除草剂がこの酸素電極法で光化学的リン酸化の阻害剂 として作用する可能性が見いだされた時には，Avronの

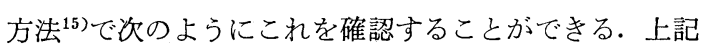
の反応液に $10^{6} \mathrm{cpm}$ の ${ }^{32} \mathrm{P}$ リン酸を加え, 1 分間照射 し, 反応液をイソブタノールーベンゼン一水で抽出したあ と, 水層の放射能を測定し, この值を除草剤の有無で比 較する.

\section{3. タイプ $\mathrm{A}$ 葉緑体による $\mathrm{CO}_{2}$ 固定能の測定 ${ }^{13)}$}

上述の完全葉緑体 (タイプ A) による $\mathrm{CO}_{2}$ 固定をみ るには, 反応液として，0.33 M ソルビット， $20 \mathrm{mM}$ EDTA, $1 \mathrm{mM} \mathrm{MgCl}_{2}, 1 \mathrm{mM} \mathrm{MnCl} 2,50 \mathrm{mM}$ HESPES$\mathrm{NaOH}$ 緩衝液（pH 7.6）の組成のものを用い，これに クロロフィル濃度が $100 \mu \mathrm{g} / \mathrm{ml}$ となるよう上記葉緑体を 懸垂させ，その $1.5 \mathrm{ml}$ を用い，これに $\mathrm{NaH}^{14} \mathrm{CO}_{3}$ 溶 液（最終濃度 $10 \mathrm{mM}$ ) を加え, $22^{\circ} \mathrm{C}$ の恒温槽中 20.000 lux の白熱電球で照射する. 一定時間ごとに最終濃度 10\% の酢酸を加えて反応を中止し，一定量の酸性葉緑 体懸垂液を試料皿にとり出し, 乾燥後 $\mathrm{GM}$ 管で固定さ れた ${ }^{14} \mathrm{C}$ の放射能を測定する. 上記の方法で調製された 
葉緑体は $60 \sim 70 \mu$ moles $\mathrm{CO}_{2} / \mathrm{mg}$ クロロフィル・hr 程 度の活性を示す。

\section{4. タイプ $\mathrm{C}$ またはタイプ $\mathrm{E}$ 葉緑体による Hill 反 応測定とこれに共役した光リン酸化反応測定}

宮地 ${ }^{13)}$ の方法を紹介する. 反応液組成は，フェリシア

ン化カリ $0.8 \mu$ mole, ATP $1.0 \mu$ mole, $\mathrm{NaH}^{32} \mathrm{PO}_{4} 30$ $\mu$ moles (約 $10^{6} \mathrm{cpm}$ ), $\mathrm{MgCl}_{2} 2 \mu$ moles, グルコース 20 $\mu$ moles, ショ糖 $300 \mu$ moles, トリシン $-\mathrm{NaOH}(\mathrm{pH} 9.0)$ $100 \mu$ moles, ヘキソキナーゼ $1 \mathrm{mg}$ ，クラス C または $\mathrm{E}$ 葉緑体（クロロフィル $40 \mu \mathrm{g}$ ）である. これを $20^{\circ} \mathrm{C}$ の 恒温槽中で光を照射し $(20,000$ lux $), 12 \%$ トリクロル 酢酸を加えて反応を停止させ，遠心分離して葉緑体を除 き, 上清の $420 \mathrm{~nm}$ の吸光度（黄色）の減少からフェリ シアナイド (Hill oxidant) の光還元量を計算する（その $420 \mathrm{~nm}$ に打恔子分子光係数は $1.02 \times 10^{3} \mathrm{M}^{-1} \mathrm{~cm}^{-1}$ であ る). 光リン酸化能は, 未反応の無機 ${ }^{32} \mathrm{P}$ をリンモリブ デン酸としてイソブタノールで抽出し，残った有機りン 区分の放射能を測定して求める.

国内の研究で，除草剤の葉緑体光化学反応への影響を 扱った研究例として, 中村ら ${ }^{16)}$ の酸ア之ド系除草剂, 白 川17)の CMMP, 百武ら ${ }^{18)}$ の CNP, 嶺ら ${ }^{19)}$ のベンタゾ ンなどをあげることができよう。また，クロロフィル生 成阻害に関する実験のモデルとしては藤井 ${ }^{20)}$ の報告を有 効に利用することができよう.また，理学部系の DCMU を阻害剤として使用した数多くの基礎的研究（おもに Plant and Cell Physiology に発表されている）にも注目 する必要があろう。

\section{タンパク質および核酸生合成への影響}

DNA・RNA を通してのタンパク質生合成の阻害も 除草剤の重要な作用点である.これは未分明の部分も多 いが，後述のオーキシン作用をもつ除草剂と同様に奇型 を生ずるという外観でもある程度判定がつく作用点であ る. EPA の報告書では，トウモロコシ幼根の根端切片 への放射性核酸塩基やアミノ酸のとりこみを調べ，これ に対する除草剤の影響を判定している.

\section{1. トウモロコシ幼根の根端切片による取込み実験}

トウモロコシ種子を種子消毒したあと，よく水洗し， 通気しながら 6〜8 時間大きい容器に浸積し，孔をあけ たアルミニウム板上に一層となるよう拡げる. 水道水を 種子のレベルにまで入れて暗所 $20^{\circ} \mathrm{C} て ゙ 3$ 日間発牙させ る.

トウモロコシ主根の先端 $3 \mathrm{~mm}$ を切断し，5\%(v/v) Clorox 液 (次亜塩素酸ソーダの水溶液製品) に5 分間浸 漬して表面殺菌する. これを滅菌水で数回洗浄する.
10 25 本の根端切片を $0.5 \mathrm{ml}$ の $50 \mathrm{mM}$ 滅菌グルコー スおよび所定量の除草剤を含む反応液を含む小型フラス コまたはバイアルに入れる. 30 分間放置後, 少量の ${ }^{14} \mathrm{C}-$ ロイシン $+{ }^{3} H$-チミジン，または ${ }^{14} C$-ウリジンを加え る. 放射性物質はキャリアーなしで 1 または $2 \times 10^{6} \mathrm{cpm}$ の活性をもつものとする. 反応液は $25^{\circ} \pm 1^{\circ} \mathrm{C}$ で所定の 時間（ふつう 2 時間）振湓して通気する. 放射性添加後 2 時間で，根端切片を滅菌蒸溜水ですばやく洗浄し， DNA，RNA およびタンパク質に分画する。

\section{DNA，RNA およびタンパク質の分画}

EPA 報告書において，Bowman らは過塩素酸を用い る方法よりここでの目的に適合するものとして酵素を用 いる方法を提案している. 第 1 法と第 2 法とがあるが， 後者のほうでよりよい結果が得られているので，これを 紹介しておく.

1) ${ }^{14} C$-ウリジンの RNA へのとりこみ

$0.5 \mathrm{ml}$ の反応液中の根端切片を滅菌蒸溜水でよく洗 い, $5 \mathrm{ml}$ の $75 \%$ エタノール $\left(0 \sim 4^{\circ} \mathrm{C}\right)$ 中でテフロング ラインダーを用いて磨砕する．DNA，RNA およびタン パク質を沈澱として遠心分離で集める（以下の遠心分離 はすべて $10,000 \times g 15$ 分, Sorvall 冷却遠心機 RC-5 で swinging bucket rotor を用いて行なった). 生じた沈澱 を $0.1 \mathrm{M}$ 酢酸ナトリウム緩衝液 ( $\mathrm{pH} 5.0) 1 \mathrm{ml}$ (2 mg の RNAase，シグマ社製タイプ XI-A を含む）に懸浊さ せ， $37^{\circ} \mathrm{C}$ で 4 時間処理する. 処理後 DNA とタンパク 質は $4 \mathrm{ml}$ の冷エタノールを加え，遠心分離する.この 沈澱を $2 \mathrm{ml}$ の $75 \%$ エタノールで洗浄し, 両方の上清 液の放射能をカウントする.

2) ${ }^{3} H$-チミジン $+{ }^{14} C$-ロイシンの， とれぞれ DNA およびタンパク質へのとりこみ

1）の方法と同じように根端切片を水洗して磨砕し， 冷エタノールで沈澱を得る.この沈澱を $0.4 \mathrm{mM} \mathrm{MgCl}_{2}$ および $2 \mathrm{mg}$ DNAase（クロマトグラフ調製デオキシリ ボニュークレアーゼ I, シグマ製) を含む $1 \mathrm{ml} 00.1 \mathrm{M}$ トリス塩酸緩衝液（pH 8.0）に均一に懸浊し， $37^{\circ} \mathrm{C}$ で 4 時間処理する. 反応後これに $1 \mathrm{ml}$ の $1 \mathrm{~N}$ 過塩素酸を 加え（最終濃度 $0.5 \mathrm{~N}$ )，タンパク質と RNA とを沈澱 させる. 混合物を遠心分離し，上清を DNA 分析のため シンチレーションカウンターで計測する．沈澱は $100 \%$ エタノールに懸浊し, Schleider \& Schuell のフィルター （\#595）で濾過し，タンパク質および RNA を含むフィ ルターを再びエタノールで洗い，シンチレーションカウ ンターでカウントする.

除草剂は，反応液へ DMSO（最終濃度で $1 \%$ 以下） 液に溶かして加えられた。 
除草剂のタンパク質生成阻害剂としての特徴や作用機 構については，小林と石塚の解説 ${ }^{21)}$ 参照されたい。 た国内で行なわれたタンパク質生成阻害の除草剂研究と

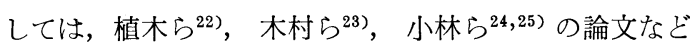
がある。

\section{オーキシン作用の検討}

2,4-D 等の示すいわゆるオーキシン作用も除草剤の作 用としては重要なものである。したがって，ある除草剤 の作用機構を判定するテストのひとつとして，オーキシ ン作用があるかどうかを検定しておく必要がある．除草 剂として施用したとき，その外観変化から，いわゆる形 成作用（formative effect）を示す場合，あるいは上偏生 長 (epinasty) をおこす場合などには，その作用機構を オーキシン作用と判定できる場合が多いが，詳細には， 以下のような試験をし 2,4-D やインドール酢酸などと くらべてどのくらいの相対值を示すかを見ておく必要が ある・

オーキシン作用は生物検定法で測定されるが，いくつ かの方法がある ${ }^{26)}$.

\section{1.アベナ等の伸長試験}

材料としてはエンバク (Avena sativa L., 品種ビクト リー）が用いられるが，黄化エンドウの第 3 節間, 光の 下で育てたエンドウの第 5 節間，あるいはコムギの子葉 鞘を用いてもよい。エンバクの場合には，吸水させたバ 一ミキュライトに播種し, $27^{\circ} \mathrm{C}$ で弱い赤色光で 64 時間, さらに暗黒中に 24 時間おいて $2 \sim 3 \mathrm{~cm}$ に生長したもの を, 赤色光下で, 子葉䩗先端 $2 \mathrm{~mm}$ を切り除き, その下 $5 \mathrm{~mm}$ の切片をつくり，これを試験液の入ったシャーレ に浮かべ，一定時間後 (10〜18 時間後) その長さを測定 し，対照区との比率を求める.

屈地反応などで切片が曲がるのを防ぐため, 子葉鞘中 の第 1 葉を抜き，ガラス棒に切片を通すことも行なわれ るが，伸長生長そのものは第 1 葉を抜かないもののほう が大きい. 切片の曲がるのを防止するには，切片を浮か ベた溶液をゆっくりと振盪または回転すればよい。 ま た，試験液への添加物としては， $1 \times 10^{-2} \mathrm{M}$ リン酸緩衝

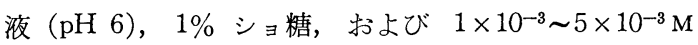
硫酸マンガンの組合せがよいとされている.

\section{2. 根の伸長阻害試験}

一般に植物の根はオーキシン類にたいして敏感で，か なりうすい濃度でその伸長阻害を示すため，これが生物 検定として利用される. 材料としては, セイヨウカラシ ナ (Lepidium sativum) やアマ (Linum usitatissimum L.) などが使用される. 前者の場合，根長が $1 / 2$ になる
インドール酢酸濃度は約 $0.05 \mathrm{ppm}$ である.この系で逆 の作用を利用して抗オーキシン活性をもテストすること ができる.

以上のほかに，繁雑ではあるが古典的標準法としての アベナ屈曲テスト，エンドウ䔄のわん曲状態をしらべる エンドウ届曲試験（スプリットピーテスト），あるいは イネの葉身基部の角度がオーキシン投与で増大するのを

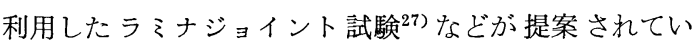
る. ラミナジョイント試験は，オーキシン共存下では夕 ンパク質生合成試験として取り报うこともできる ${ }^{23)}$.

\section{おわりに}

以上, 紙数不足ながら, 除草剂の作用機構研究におけ る生理化学的手法の一部を紹介したが，本文中でもふれ たように次のようなことに留意する必要がある。すなわ ち，ミトコンドリアや葉緑体を用いた生化学的な実験で は，除草剤の最終作用点またはそれに近い部位における その作用力の比較は可能であるが，その結果をただちに 実際に使用する条件における殺草力あるいは抵抗性・感 受性の差（選択性）と結びつけるのには問題がある. 別 の言葉では, in vitro の実験とin vivo の実験との間に は差を意識する必要があるともいえよう。この差には， 除草剂の物理化学性, とくに透過性・移行性, あるいは 環境での残効性・移動性等が関与していると考えられ る.

また，除草剤の 別の特性である 選択性機構について は，抵抗性植物にお污るとの除草剂の分解や抱合等の生 化学反応による解毒反応などがかなり重要な位置を占め るので，生化学的手法による実験結果もまた重要性をも つことになる.

なお，除草剤の作用機構および選択作用性の生化学的 側面については，それぞれ松中 ${ }^{28)}$ および石塚 ${ }^{29)}$ の解説 を参照されたい。

末筆ながら，資料をいただいた林文彦博士に深謝しま 于.

\section{引用文 献}

1) 林 文彦：農薬誌 1, 153 (1976)

2) 名和義彦 - 旭 正：蛋白質 核酸 酵素別冊 生 体膜実験法 上，共立出版，p. 304，1974

3）旭正 - 岩槻紀夫：蛋白質 核酸 酵素別冊 植 物醅素・蛋白質研究法, 共立出版, p. 91, 1976

4) N. E. Tolbert: Methods Enzymol. 31, 734 (1974)

5）赤堀四郎編：酵素研究法III, 朝倉書店, p. 382, 
1957

6) 吉川春寿ほか編：化学の領域増刊 13 ワールブル グ検圧計，南江堂，p. 180, 1954

7）関根隆光ほか編：化学の領域増刊 20 続ワールブ ルグ検圧計，南江堂, p. 356, 1955

8）萩原文二編：電極法による酸素測定，講談社，p. 126, 1977

9) R. W. Esterbrook: Methods Enzymol. 10, 41 (1967)

10）松中炤一：農薬一デザインと開発指針一（山本 出・深見順一編)，ソフトサイエンス社， p. 401, 1979

11）松中昭一：農化 39, 135 (1965)

12）文献 10)，p. 367

13）宮地重達：蛋白質 核酸 酵素別冊 植物酵素 - 蛋 白質研究法 (森田雄平ほか編)，共立出版， p. 64, 1976

14) D. I. Arnon: Plant Physiol. 24, 1 (1949)

15) M. Avron: Biochim. Biophys. Acta 40, 257 (1960)

16）中村 拓 - 松中昭一: 雑草研究 8, 33 (1969)

17）白川憲夫：杂隹草研究 9, 11 (1969)
18）百武 博 - 石塚皓造：第 14 回日本雑草学会講演 会講演要旨集 p. 127 (1975)

19) A. Mine \& S. Mastunaka: Pestic. Biochem. Physiol. 5, 444 (1975)

20）藤井保男： 農薬誌 4, 391 (1979)

21）小林勝一郎・石塚皓造：農薬一デザインと開発指 針一(山本 出・深見順一編), ソフトサイエンス 社, p. 415, 1979

22）植木邦和・山末祐二・片子沢朋子：雑草研究 $\mathbf{1 0}$, 36 (1970)

23）木村一郎 - 一前宣正 - 松中昭一 雑草研究 12, 54 (1971)

24) K. Kobayashi \& K. Ishizuka: Weed Sci. 22, 131 (1974)

25) K. Kobayashi \& K. Ishizuka: J. Pesticide Sci. 2, 59 (1977)

26）増田芳雄・勝見允行・今関英雅：植物ホルモン, 朝倉書店, p. 32,1971

27）前田英三・河村雄司：日作紀 31，61（1962）

28）松中昭一：文献 21)， p. 329

29）石塚皓造：文献 21)，p. 752 